\title{
Staphage Lysate
}

National Cancer Institute

\section{Source}

National Cancer Institute. Staphage Lysate. NCI Thesaurus. Code C1236.

A preparation of bacterial lysate with potential immunomodulatory activity. Staphage lysate, obtained by phage lysis of Staphylococcal aureus, may be used as an antigenic stimulus to elicit non-specific humoral and cellular immune responses. 